not, the average per capita income in Spain is only about $£ 270$ in spite of a fairly fast economic growth for several years now. So far, the attempts to suppress these committees have served to unify their members, whose sympathies range from Christian socialism to Trotskyite communism and anarchism.

\section{CONTINENTAL SHELVES}

\section{More Cousi-More Sea Bed?}

$\mathrm{BY}$ eleven votes to six, the International Court of Justice at the Hague has recognized that West Gernany's concave coastline puts her at a disadvantage compared with the Netherlands and Denmark when the North Sea continental shelf is divided up geometrically, according to principles defined at the 1958 Geneva Convention, and has ruled that the boundaries should be redrawn by agreement between the countries, taking into account factors such as the length of the coastlines.

The dispute between Germany and her neighbours has been simmering since 1958 when the Geneva Convention made a ruling that lines drawn perpendicular to the coast should delimit the areas of continental shelf belonging to each country. As the map shows, this kind of division is unfavourable to Germany, and the International Court, delivering judgment on Germany's claim for a bigger area, held that such geometrical division is not a rule of customary international law and that the area must be partitioned according to "equitable" principles. Each country has "an original right to those areas of the continental shelves which constitute the natural prolongation of each nation's territory into and under the sea", but other factors such as usage of the ocean and the capability of a country to exploit the sea bed should be considered.

As well as establishing an interesting legal precedent-this is the first case of its kind to be brought before the International Court-this decision may have industrial repercussions. International oil and gas exploration companies operating in the United Kingdom sector and with concessions in the Dutch area may be affected by the pending boundary changes. British Petroleum Ltd has two blocks almost on the median

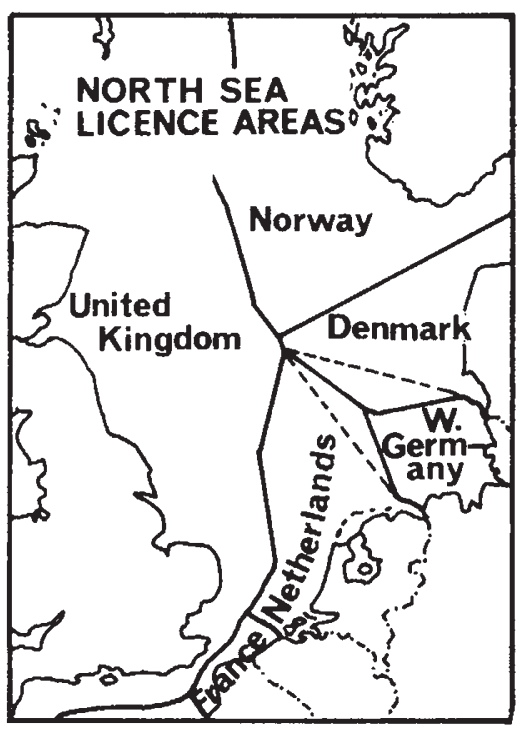

Dotted lines show possible extension of German zone. line dividing the German and Dutch sectors, and this may cause some argument, although concessions that have already been granted in transferred areas are usually automatically recognized. The verdict is also likely to initiate litigation in other offshore oil and gas exploration areas, such as the Persian Gulf where the boundaries are in dispute.

Although the law of the continental shelf has to some extent been clarified by the Geneva Convention, which is intended to be a declaration of customary international law on the subject, it is still, like the law of outer space, somewhat breathlessly trying to keep pace with technology. The continental shelf, for example, has been defined as the sea bed adjacent to the coast to a depth of 200 metres or "to where the depth of the superadjacent water admits the exploitation of the natural resources of such areas" so that lawyers are now trying to get international agreement on a law for the exploitation of the deep seas to avoid a situation where the world's oceans are divided up between countries with the technological expertise to explore the sea bed at progressively deeper levels.

Since the General Assembly in 1967, when the Maltese delegation first suggested that the sea bed beyond the limits of national jurisdiction should be reserved for peaceful purposes and its resources used in the interests of all mankind, the United Nations has been considering the problems involved. A committee was set up in 1967 to consider whether the ocean floor should be reserved for peaceful activities and what exactly the resources of the ocean floor may be, and this reported to the General Assembly last year. A permanent committee has now been set up to consider the report and to discuss, among other things, the possibility of setting up a permanent international body with complete jurisdiction over the sea floor.

\section{ENERGY}

\section{Last Hope for Coul}

THE British coal industry has the very best of incentives for technological change. Without it, it is doomed to play the part of a poor relation, supplanted by the glamour of nuclear power, oil and even gas. One of the more substantial straws at which the industry has been clutching is provided by a new method of burning coal which is under development in a number of centres in Britain and the United States. The new method offers better heat efficiency at a much lower cost than conventional coal boilers, and it is by no means hard to see it as coal's last chance of retaining a part of the electricity generation market.

Instead of burning coal in a solid grate, the new method makes use of a bed of ash, turned into a fluid by air flowing upwards through it. (The principle is exactly that demonstrated to generations of schoolchildren at the Royal Institution by Sir Lawrence Bragg. A rubber duck is immersed in a barrel of sand, while a steel ball-bearing rests on the surface; air is blown through the sand, giving it the properties of a fluid, and the ball-bearing sinks while the duck floats to the surface.) Into the bed of ash is injected finely divided coal, which disperses rapidly through the bed as it burns in the stream of air. The heat generated is extracted by boiler tubes which pass through the bed itself, an arrangement which gives very high heat extraction rates and keeps the temperature down to 


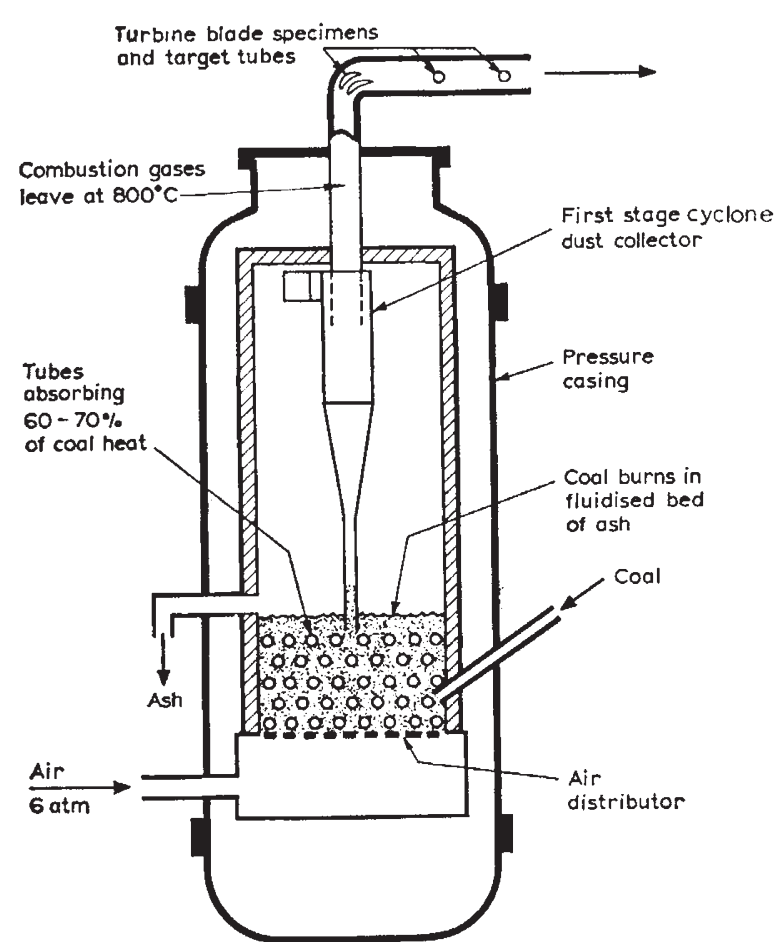

The fluid-bed combustor and turbine blade test section being built at BCURA. (Courtesy, BCURA Gazette.)

about $700^{\circ}-800^{\circ} \mathrm{C}$. At this temperature, the ash does not form solid lumps of clinker, but remains in the finely divided form which is essential for the formation of the fluidized bed. Because the bed is almost 95 per cent ash and only 5 per cent coal, very poor grades of coal with a high ash content can be used, and coal preparation costs can be minimized. The high heat extraction rates mean great reductions in boiler size, and because the temperature is comparatively low, fouling and corrosion of the boiler tubes should be slight.

Even greater economies are possible if the entire boiler is operated at high pressure, and work at the British Coal Utilization Research Association is directed at developing this concept. Even further reduction of the boiler size is possible (down to $1 / 20$ the size of conventional boilers), and the exhaust gases, after cleaning, are used to drive a gas turbine. By the end of this year the staff at BCURA hopes to have precise calculations of the costs of a $140 \mathrm{MW}$ unit, in which $20 \mathrm{MW}$ would be generated by a gas turbine and the rest by a steam turbine. Much depends on how efficiently the exhaust gases can be cleaned before they enter the gas turbine, and the test programme at BCURA includes the construction of a pressurized boiler whose exhaust will impinge on Nimonic turbine blades to gain information about rates of erosion, corrosion and deposition. The hope is that the low combustion temperature will minimize the amount of corrosive alkali metal compounds in the exhaust gases.

Another test rig at BCURA uses a second fluidized bed in series with the first, vertically above it in the boiler. The function of this bed is to act as a heat exchanger, because some further method of extracting heat is needed; the primary bed extracts only $50-60$ per cent of the heat available. The second bed, operating at a lower temperature than the first-around $260^{\circ} \mathrm{C}$-would also act as a trap to prevent carry-over of particles, and with suitable additions it could be used as a means of removing sulphur from the exhaust.

The staff at BCURA is well aware that time is running out. "The time-scale must be short," says Mr A. G. Roberts, who is responsible for the test facility. If fluidized bed combustion is not realized commercially within five to ten years, it will be too late. But if all goes well, BCURA sees opportunities in industrial scale plant as well as in the export market. At the moment, nobody really believes that the Central Electricity Generating Board can be swayed from its devotion to nuclear plants; equally, nobody is admitting this publicly, least of all Lord Robens.

Meanwhile, BCURA is to regularize its relationship with the National Coal Board by becoming a wholly owned subsidiary. It will still, however, undertake work for industry on a contract basis, and is now actively looking for work of this sort. Although the laboratory knows most about coal, it has gathered over the years a great deal of experience in combustion, high temperature technology, automatic control, and the characterization and handling of solids.

\section{STEEL RESEARCH}

\section{Change Round at BISRA}

SiR Charles Goodeve, who retires this week as director of the British Iron and Steel Research Association, can look back on an enviable record. BISRA is a thoroughly good organization and Sir Charles, who has been director since 1945, deserves a good deal of the credit. Unlike other research associations, BISRA has never allowed "collaborative research" to be a synonym for mundane investigations of members' problems. BISRA does its share of trouble-shooting, but at the same time it has managed to undertake ambitious and far-reaching research programmes, and this in an industry not noted for its willingness to innovate.

Two of the important investigations in progress illustrate this well. The Ironmaking Division, with support from the Physics Department, is working on the continuous production of iron direct from the ore, using a tube-shaped furnace rotating at high speed. In effect, the furnace is a cylinder tilted at about $5^{\circ}$ from the horizontal, and rotating about its axis. Iron ore, coal and oxygen are fed in at the upper end of the cylinder, and react as they flow down the furnace to the lower end. Coal is used as a cheap reducing agent, and reacts (as carbon) with the ore to produce iron and carbon monoxide. The heat for the furnace is supplied by the reaction of the carbon monoxide with oxygen to produce carbon dioxide. A similar process, developed in Sweden, suffered from excessive refractory wear because the inner surface of the furnace was constantly wetted by the flow of molten iron ore. BISRA is attempting to get round this difficulty by the bold expedient of rotating the furnace fast enough for it to behave as a centrifuge, with the heaviest constituent, iron, thrown to the outer layer. The hope is that the iron, by forming a layer over the refractory surface, will protect it from liquid iron ore. The chief doubt is whether the heat transfer from the hot gas core of the furnace to the solid reactants at the perimeter will be sufficient to maintain the reaction. To 